\title{
WORK-RELATED CONCERNS OF SOUTH AFRICANS LIVING WITH HIV AND AIDS
}

\author{
DIANNE MALOON \\ FREDDIE CROUS \\ ANNE CRAFFORD \\ Department of Human Resource Management \\ Rand Afrikaans University
}

\begin{abstract}
Aspects relating to the management of HIV and AIDS are issues of extreme importance in South Africa at present. In light of this, a qualitative study was conducted to explore the work-related concerns of Black South Africans living with HIV and AIDS. Semi-structured interviews with 22 participants revealed that work-related concerns cannot be understood outside of general financial constraints and relationship issues. Additional categories emerging from the study are: coming to terms with HIV, fear of disclosure, job-related barriers and coping mechanisms. The implications of these findings are discussed and recommendations made.
\end{abstract}

\section{OPSOMMING}

Aspekte rakende die bestuur van HIV en VIGS doen hulle voor as vraagstukke wat van kardinale belang is in die Suid-Afrikaaanse opset. In die lig hiervan is ' $n$ kwalitatiewe studie uitgevoer ten einde die werkverwante besorgdhede van swart Suid-Afrikaners met HIV en Vigs, te ondersoek. Semi-gestruktureerde onderhoude met 22 deelnemers het aan die lig gebring dat werkverwante besorgdhede moeilik, buite die konteks van algemene finansiële beperkinge en verhoudingsvraagstukke, te verstaan is. Addisionele vraagstukke wat geïdentifiseer is, is om tot aanvaarding te kom met HIV, vrees vir bekendmaking van HIVstatus, werksverwante hindernisse en hanteringsmeganismes. Die implikasies van hierdie bevindinge is bespreek en aanbevelings is gemaak.

The importance of work in achieving a sense of wellbeing is well documented. Human beings need to feel that there is a goal to strive towards, something to live for and that life has a purpose (Shantall, 1997). Meaning is contained in a sense of futuredirectedness and life is experienced as meaningful when people have a vocation in life or a mission to fulfill. Work provides purpose and dignity and allows people to achieve a unique personal existence (Hunt, Jaques, Niles \& Wierzalis, 2003; Lukas, 1997). It furthermore sustains biological survival and satisfies needs for affiliation, interpersonal contact and social identity (Schreuder \& Theron, 2001).

Being diagnosed HIV positive impacts the medical, psychological, social, spiritual, educational and economic life of the infected person, affected others and the community as a whole (van Dyk, 2001). It opens up a huge fissure in the world of the infected and at a very basic level individuals begin to ask the question: why me? (Gergen \& Gergen, 2003). This challenges people to confront isues such as the meaning of their lives. People with a positive diagnosis are faced with the task of integrating this diagnosis into their self-concept and career goals (Hunt et al., 2003; Hoffman, 1997). According to Bartos and McDonald (2000), a positive diagnosis may be integrated as an identity, an experience or as a career. Where HIV is integrated into identity and expressed in career, re-integration into the world of work is more likely. Bartos and McDonald (2000) found that for some, HIV presented work opportunities in the AIDS industry. In these instances, crisis becomes an opportunity for development (Riegel, 1979). However, when initially confronted with existential confusion, many HIV positive people question the purpose of advancing their careers, some despairing that they will not have enough time to attain their goals (Hunt et al., 2003; Lukas, 1997).

The reality is that people respond differently to HIV. While some may deteriorate rapidly within five to seven years, others remain relatively healthy for as long as ten to 20 years (van Dyk, 2001). Furthermore, antiretroviral therapy allows people living with HIV to live longer, have a better quality of life and experience

Requests for copies should be addressed to: F Crous, Department of Human Resource Management, RAU University, PO Box 524, Auckland Park, 2006 fewer illnesses (Hunt et al., 2003). Since access to anti-retroviral medication is on the increase in South Africa, lifespan and quality of life for HIV positive people with access to this medication can be expected to increase. With an increased lifespan, it is likely that motivation to plan for re-entry into the marketplace and continue with career will improve.

South Africa is faced with a high incidence of HIV coupled with a high unemployment problem. According to an HIV prevalence surveillance done by Evian (2003) in numerous workplaces in Southern Africa, the prevalence ranges from approximately 5\% to $30 \%$ (C. Evian, personal communication, 5 November 2003). According to UNAIDS (2002), 26,5\% of pregnant women in South Africa between 15 and 49 tested positive for HIV. This presents a challenge which must be negotiated within the context of large-scale unemployment and poverty. Unemployment in South Africa is remarkably high and rising (Kingdon \& Knight, 2001). In September 2001, unemployment in South Africa was estimated at $41,8 \%$ on the broad definition (those wanting work) and 30,5\% on the narrow definition (those in active job search) (Kingdon \& Knight, 2001). Klasen (2000) found unemployment rates to be highest amongst rural Africans and households headed by single females. This is exacerbated by the fact that the country has virtually no unemployment insurance system.

High unemployment is combined with the propensity of HIV positive people to lose their jobs as the disease progresses, often as a result of discrimination (Hoffman, 1997; Hunt et al., 2003). According to Jackson (2002), people with HIV have been thrown out of their families, sacked from employment, denied access to services and excluded from gatherings and events, all as a result of unrealistic fears amongst the public.

Government's plan for dealing with HIV and AIDS in South Africa focuses on funding and providing anti-retroviral treatment. Likewise, organizations like Love Life, the Treatment Action Campaign and the World Health Organisation have focused on the medical aspects of HIV and AIDS. Other areas on which government has focused include prevention, education about HIV and AIDS, methods of boosting the immune system, 
treatment of opportunistic infections and support programmes for affected members (Cabinet statement on comprehensive treatment and care for HIV and AIDS in South Africa, November 2003). In view of this, HIV positive people are likely to live longer, more productive lives. In this case, issues around getting back to work, job advancement and establishing small business especially in the informal sector are likely to become more important. Under these circumstances a greater emphasis on dealing with work-related issues of HIV positive people, for example creating work opportunities and stigma-free workplaces would be beneficial.

Career concerns have been studied amongst White Americans (Hunt et al., 2003) but no qualitative study of work related concerns amongst Black South Africans with HIV has been conducted.

The aim of this research was to explore work-related concerns of HIV positive people in South Africa. Work-related concerns in this context refers to aspects preventing HIV positive people from accessing work, keeping work and advancing in their jobs. The question asked was: what challenges do HIV positive people face as they try to get work in the formal sector or generate an income in the informal sector? What were their work related concerns?

\section{METHOD}

In exploring the work-related concerns of black South Africans living with HIV and Aids, a qualitative research design was followed. The qualitative approach allows participants to give expression to their socio-political and cultural situation (Smaling, 1992). This was important because the impact of HIV and AIDS on finding work and maintaining a livelihood cannot be fully explored in isolation from the socio-economic context in which participants find themselves. This is critical in this study where many of the interviewees had been socially and politically marginalised. Using this approach, the goal was to establish how the participants in this study construct meaning with regard to their working lives in the context of their socio-economic conditions.

\section{Participants}

A sample of convenience was drawn from the population of HIV positive black South Africans living in Gauteng. Twenty-two black South Africans who had been diagnosed with HIV were interviewed. Participants resided in Alexandra and Soweto in Gauteng. Participants attending the HIV/AIDS weekly support group meetings at the Mandela-Sisulu Clinic in Soweto were briefed about the research and invited to participate. Interested individuals volunteered. Participants were at various stages of disease progression. One had developed full-blown AIDS.

Participants ranged in age from 20 to 42 and fell within the economically active sector of the population. Of the 22 participants, five were male and 17 female. Of the 17 females, 11 were single mothers with children and extended family. Twenty of the participants contracted HIV through sexual contact, one through blood transfusion and another through blood contamination. Seventeen participants had been diagnosed with HIV from one month to four years prior to the study. The remaining five had been diagnosed five, nine, two at 11 and one at 23 years prior to the study.

With regard to education, 11 had matriculated, four of whom had studied beyond matriculation level. The other 11 had achieved between grade eight and grade eleven education levels.

With regard to employment, 14 were currently unemployed, some having been previously employed. Four were selfemployed, one was in part-time employment and three were doing voluntary work. Participants' occupations included printer, caterer, salon and tavern owner, sales assistant, labourer, electrician, tour guide, jeweler and HIV counselor.

\section{Procedure}

It is a requirement in terms of the Constitution of the Republic of South Africa, 1996 Section 12 (2) that issues of informed consent are respected for all research conducted in South Africa. In the case of research on HIV and AIDS consent must be obtained from an ethics committee authorized to grant permission. Application to proceed with the research was submitted to the Ethics Committee of the Department of Health, Gauteng on 22 May 2003. This committee was approached since the Mandela-Sisulu clinic falls under their auspices. A research protocol outlining all aspects of the research was requested and submitted. Permission to proceed with the study was obtained from the Department of Health, Gauteng on 20 August 2003.

After receiving a full explanation of the research objective, benefits and procedure, informed consent was obtained from each participant. Participants who indicated that they were keen to participate in the research signed a consent form indicating that they understood the research objective, procedure and that they were willing to participate voluntarily. Permission to taperecord the interviews was obtained. Participants were informed that interview data would be kept confidential and reporting would be anonymous. Transcripts were shared only with the researcher and supervisors and no participants were identified in the research article. Data was collected using semi-structured interviews from between 60 and 90 minutes.

Using the narrative approach, participants were asked to describe their story with an emphasis on the effect of their diagnosis on their work situation. The narrative approach was not inappropriate to the culture of the sample given their traditional use of story-telling (De Vault, 1999). Participants expressed their pain, anguish, opinions and ideas in their own words. Their stories were heard through uninterrupted narration. In this way the aim of understanding concerns from the participants' perspective was achieved (Esterberg, 2002). This method empowers participants and contextualises the interview process (Smaling, 1992). Questions were openended and guided by a general plan of inquiry (Babbie \& Mouton, 2001). Questions such as "how did that (whatever had been expressed) impact your work prospects" were only asked after significant self-expression had taken place and only where participants had moved significantly away from the topic of workplace concerns. Standard information such as medication, years of infection and employment status were obtained, as it was believed that these aspects impact work related concerns.

The researcher conducted the interviews. As a facilitator of a counseling training programme, the researcher is familiar with interviewing techniques. Listening, paraphrasing and reflecting were the main skills used during the interviews. Interviews were audio taped and transcribed.

Data was analysed through an iterative process of theme identification and in conjunction with field notes. Analysis took cognisance of both the external reality, for example being unemployed and the internal experience, for example response to HIV (Silverman, 2000).

\section{Managing threats to validity}

In order to minimize random error, one interviewer conducted all the interviews over a period of three weeks. As indicated, interviews were conducted at the Mandela-Sisulu clinic during the mornings from 9am until 12am. Between two and three interviews were conducted per morning depending upon availability of interviewees. Where three interviews were conducted, reliability could have been affected. The venue and time was used because participants regularly visited the clinic at this time and knew its location. Most participants were single mothers with children who came from the same area with similar living conditions. 
The interviewer was a white female and all interviewees were black. Smaling (1992) notes that in any interaction, bias and prejudice are continually being confronted. In order to address this, a standard introduction and interview process was used for every interview. Care was taken to ensure that every interviewee understood the purpose of the interview, what they stood to gain from the process. As indicated, confidentiality was assured. Participants benefited from the interviews because of the cathartic nature thereof. In addition, participants were offered the opportunity to attend a workshop to assist them in planning to find work and advance their careers.

Respondents were receptive, open and told their stories freely and in detail. In this sense, Smaling's (1992) notion of objectivity as "letting the object speak" was adhered to. For all interviews, the interviewer took the participants seriously, displayed empathy and positive regard for respondents. Detailed field notes were kept and used in the interpretation of the data. The interviews were transcribed and data analysed under the supervision of study leaders.

\section{RESULTS}

It was found that the work related concerns of people interviewed could not be considered in isolation from the socioeconomic conditions facing them nor the political history of South African society.

In analysing the data, six categories emerged:

1. Financial concerns

2. Relationship difficulties

3. Coming to terms with an HIV positive status

4. Fear of disclosure

5. Job-related barriers

6. Coping with HIV and AIDS

The first two categories, financial concerns and relationship difficulties emerged from the socio-economic conditions participants found themselves in. Although these do not relate directly to work issues or HIV status, they were retained as categories because they emerged as primary concerns for participants as they prevented them from achieving success with finding sustainable work in the fields of their choice. Without money and with difficult, destructive relationships with parents, the support systems which would normally facilitate income generation capabilities were absent. In this sense they formed part of the larger context within which participants had to negotiate the challenges of living with HIV and AIDS. The next four categories: coming to terms with an HIV positive status, fear of disclosure, job-related barriers and coping with HIV and AIDS are work-related and directly related to HIV status. Thus the first two categories presented the context for the following four. Participants had to negotiate the tasks of being HIV positive in the context of financial difficulty and poor relationships.

\section{Category 1: Financial concerns}

Lack of finances was a basic, significant barrier to income generation. Most participants equated income generation with finding a job, and considered education a pre-requisite to finding a job. Since education in South Africa is not free, lack of finances inhibited getting the required education. It also impacted negatively on people's ability to manage their HIV status because there was no money for good quality food or HIV medication.

All participants reported financial difficulties and most indicated that this prevented them from pursuing their expressed work and career aspirations, which included lawyer, social worker, accountant and political analyst. The following statements were made.
"I started a course in mechanical engineering. But my parents divorced and they could no longer afford to support me financially".

"I didn't finish school because...I didn't have money".

"I could not afford to go to school or college then".

"I needed any job...I don't have money to start a business".

"I didn't have enough money to continue with school".

"My plans for the future was to be a social worker. But we had financial problems".

"My parents divorced and they could no longer afford to support me financially".

"When I was at school I wanted to be a social worker. But unfortunately with financial problems at home ... you can't achieve what you want to achieve in life".

Eleven participants could not complete their basic high school education or matric equivalent due to financial difficulties. Reasons reported for exiting school included becoming pregnant with a first child whilst at school, needing to earn money to support parents and siblings and the Soweto Riots of 1976. Of the other 11 participants who completed matric, four did so through night school. Participants who completed matric had insufficient funds to study further. Many started courses but could not continue.

Fourteen participants were unemployed. For them, the only reported sources of income were the monthly HIV grant (called disability grant), child grants and old age pensions. Under these circumstances, it becomes difficult, if not impossible, to fulfill education and career ambitions

"I live with my grandmother at home...and cousins... and uncles...all at home... in one room. We are 8 altogether. It is difficult because there is no one who is working. And the uncles are illiterate - they went out of school at standard 6".

"We all live off grandma's pension. Its tough.....it's very, very, very tough".

Participants complained about having to support parents and siblings financially as soon as they became economically active. In addition, some reported that they had to perform a parenting role for their own sisters and brothers where parents were absent.

"I had big dreams for my family... I did. For me and my family (parental family)... Because my mom was retrenched when she was very young and she couldn't find work anymore...and she was a single mother with 4 kids. And at home no one is working. I was the only one who was working".

"My mother is not working and I have to look after my younger brother".

"I did matriculate but we were a family of 4 people. I was the breadwinner.".

"I wanted to travel to Europe for tourism. But I don't want to be far from my baby sister and younger brother. They can't live alone. It's a problem. So at least when I am around I put the teddy bear in his (her brother's) bed".

Of the 17 females, 11 were single mothers with children. Several had children whilst they were still at school. Being young mothers with absent fathers, child support became a priority. One participant pointed out that a woman is not considered "valuable" until she has proven that she can bear children. Having to bear many children makes it difficult to make a good living and advance in ones career. The result was that education and career were halted at an early age. 
"I wanted to go further and do my studies. But I had to look after my four kids".

"I had my first born son when I was 15 and in standard six 6".

"I got my first born in 1986. I was 21".

"Before I matriculated, I got my first born".

"I fell pregnant with my first born in standard 7".

"After standard nine, I had my first born. Now I am staying alone with my son".

"So I didn't get the chance to get back to school because I had a child to feed and the father was not working".

"I wanted to further my studies. But it was difficult because I ended up being a single unemployed parent".

Aspects contributing to lack of finances were poorly educated and unemployed parents, single mothers supporting children and extended families, starting work whilst still at school, raising siblings and having children whilst at school. It is likely that lack of professional parents or significant others in the home contributed to the absence of professional role models. The combination of lack of finances, lack of role-models, working before completing school and bringing up siblings denied participants the opportunity to build firm career foundations.

\section{Category 2: Relationship difficulties}

Lack of care and low levels of trust characterised some participantparent relationships. Some participants were severely neglected (physically and emotionally), some abandoned, some compared negatively to siblings and some considered failures by their parents. These participants were left with low levels of self-esteem and were emotionally ill equipped to deal with the demands of getting back to work . Relationship difficulties impacted selfconfidence and self-efficacy (how effective people perceive themselves to be). This was seen to impact negatively on people's effectiveness in finding and keeping jobs as they coped with HIV.

In nine of the 22 cases, participants complained about abusive (two) and destructive (seven) relationships with parents. This is demonstrated in the following statements.

"My mother never even thought about me ... She never cared ... to come visit me ... or ask about my birthday ... or how I get on at school. My mother would just say: "Do it yourself ... anything just do it yourself".

"I don't feel supported by my mother. My stepfather tells my mother...Your daughter this and this and that. They don't give me a chance to explain".
"My mother was abused by my father. I was almost always on the street with my friends because my mother used to take it out on me. For me to become strong is for me never to go to my mother's house. During that time, life becomes better. Once I go home, she pulls me down and I lose my self confidence".

"My parents didn't want to accept anything ... they didn't want to see me grow ... they didn't have enough trust in me".

An abusive or destructive relationship with parents reduced the psychological ego-strength needed to establish good work foundations and pursue a career.

Some participants were physically prevented from pursuing careers of their choice.

"I am a dancer and love dancing. My aunt promised to kick me out of the house if I continued to dance. She was angry and shouting at me that I am not doing what she wants and I am teaching her children not to respect her".

"I love singing. I could have taken a music career. I didn't do it because I had a very strict father. He restricted me from doing an artistic career. And he used to beat me up ... physically yes. He would make me feel as if there was something wrong which I have done ... my parents were very cruel".

Participants who experienced an overwhelmingly negative relationship with significant others were preoccupied with level three of Maslow's hierarchy, the need for love and the need to belong (Maslow, 1998). Lack of love, concern and affirmation resulted in a persistent erosion of the self-esteem needed to build and develop an occupation. Furthermore poor relationships with significant others can negatively impact participant's confidence, work performance and relationships with people at work.

\section{Category 3: Response to HIV}

Whilst most participants had work ambitions, in the early stages of HIV the process of coming to terms with the diagnosis took precedence over concerns about work. Existential search was characterized by self-inquiry and questioning, for example "Why me? Why is this happening? Why won't it go away?

From the time of diagnosis, participants appeared to travel along a road from shock to acceptance as depicted in Figure 1. The phases they went through include initial shock, disbelief, denial, depression, acceptance and empowerment. The phases are discussed below. Achieving a level of acceptance of the diagnosis appeared to place participants in a state where thoughts about going back to work could be contemplated. Participants were at different points along this continuum and not everybody went through all stages reflected in Figure 1.

\section{Phases in coming to terms with HIV}

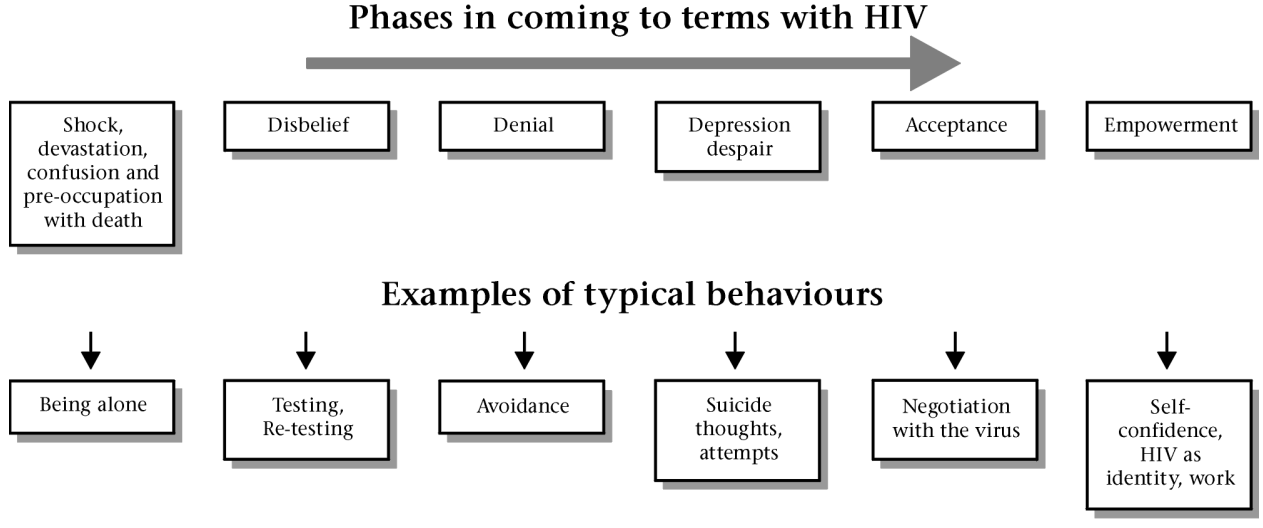

\section{Not concerned with work}


Participants who were still battling to accept being HIV positive were not concerned with their careers. This applied specifically to participants who had very recently received their results. The further participants moved towards acceptance of the diagnosis and of themselves as HIV positive, the more mental energy there was to be concerned with work issues.

Some participants were still in a state of shock.

"I was shocked that its me ... I didn't expect it to happen to me".

"I was devastated, alone and confused".

"At first I felt bad ... I felt my world is lost...I am nothing anymore ... But since joining the support group I have recovered a lot".

"I thought it was just a dream and I would wake up from this dream".

Eleven participants talked about the issue of death and seven perceived their status to be a death sentence. Two participants took to alcohol.

"The first thing you think of is death".

I haven't asked my doctor how long I have ... but maybe three to four years or so, then I will prepare for my children ... I won't go back and do matric because I don't see the time is long ... I don't have long to live ... I'll be dead by then ... for me the lifespan is short ... If only I can get time to prepare for my children".

"At first I thought I am going to die".

"If I live for five years it will be so... If it has to be seven years it will be so".

Perceived time to achieve career goals was related to perception of death. Where participants saw their positive HIV diagnosis as a "death sentence", efforts towards finding a job and pursuing a career was inhibited. Participants feared that they would be dead within five years. This meant that they had no time to study or execute other life plans. For example some stopped improving their houses. Others went into a state of suspension where nothing was done. Where HIV was seen as a death sentence, getting a job was only a concern insofar as it facilitated leaving something for the children.

"How can I have any career dreams with knowing anytime soon I will be dead. I have to just plan to have some money for my kids when I am gone".

Three of the 22 participants had attempted suicide. Others said they had suicidal thoughts.

"I tried to commit suicide three times because I was not counseled after being diagnosed and in those days HIV was still a huge taboo".

"Then I tried suicide. One year later I went to live with my granny in the Vaal triangle. I told her and she kept my secret".

Some participants were in a state of disbelief. This means that they could not entertain the thought that HIV might be a reality.

\section{"I couldn't believe it so I went back for another test".}

"The results were positive. Just to be sure, I went for another test but it was positive again so I went to Baragwanath for a third test which came out positive. Then I came to the Mandela-Sisulu clinic and just to know how true it is, I took a forth test ... that was in 2001".

Five of the 22 participants were in denial at the time of interviewing. This means that although HIV was a reality, efforts were directed towards avoiding the subject. For example one participant turned off the television or radio whenever issues of HIV or AIDS were broadcast, avoided going to support groups, avoided discussing it with any other person and denied need for medication or lifestyle changes.

"I am trying to keep it as something that has never happened. I try not to bring it closer to me".

"I don't think I have accepted that I am positive".

"They are wondering why he is sick. I said it is because he is in denial. That is why he didn't accept his status".

"It didn't affect me ... I am not sick and therefore I don't need medication".

Some participants experienced states of depression and despair:

"Sometimes I feel scared. And at the time I was so depressed and angry with myself".

"When I talk about this I cry. Most of the time I go to my room and cry".

"Then I couldn't face it. The situation was that my child and me are dying and what next".

Finally there were those who had reached a point of acceptance. Where acceptance had been achieved, there was evidence of new life emerging out of the crisis situation.

"I told myself I'm gonna take each and every day as it comes".

From now on, I don't want to stop doing things I wanted to do. If I could get into university right now, Ill still do my B comm ... I'll still do it...I'll still do it ... I'll still do it".

"I can achieve more, more, more ... more than a person who does not know his or her status. So I know mine and now my life can go on. I know where I am standing as we speak ... I can now go out and get myself a job".

"You just have to live your life and do what you want to and achieve in life. You don't need to sin ... that way you just cheat yourself."

Some participants gravitated into careers in the HIV industry, especially where they had accepted their HIV positive status and integrated it into their identities. Four participants had found jobs in the HIV field either on a voluntary or remuneration basis.

"So wherever I am going I am always carrying the anchor of acceptance. It has become my identity and my work and I am very, very happy".

"I even do the bed-bath - I can bath the terminally ill. I am brave. I do the death and dying counseling for the family and the bereavement counseling after the death".

A sense of purpose grew out of this identity, e.g. "My life's purpose now is to encourage others be proud of themselves, of their HIV status and to disclose". A passion to work in the area of HIV developed. This passion resulted in the following forms of work taking place: encouraging testing, counseling the infected and their families, the affected, doing bereavement counseling, participating in radio talk-back shows around HIV, making videos of case studies around HIV, starting support groups, conducting inspirational talks to companies, participating in and conducting HIV research, starting orphanages for HIV positive and orphaned children, giving talks at anti-natal clinics to prevent mother-to-child infection, conducting house visits and doing home-based care, training people in the community to do home-based care. 


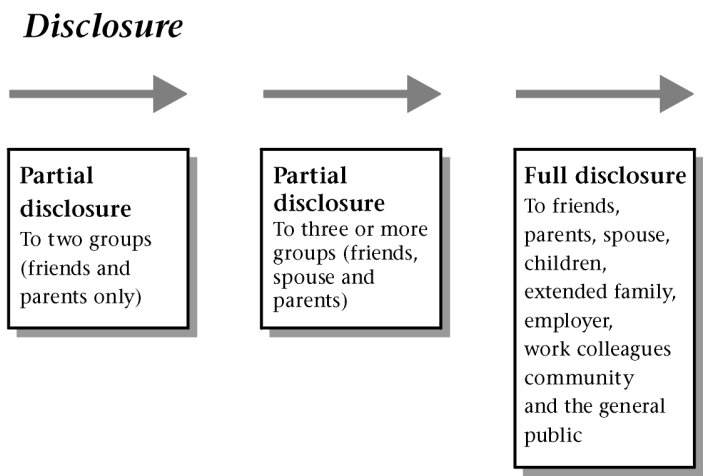

Figure 2: Path of disclosure

The phases that emerged from this study are similar to those of Kubler-Ross's stages of dying (Kubler-Ross, 1970). She identified five stages: denial and isolation, anger, bargaining, depression and acceptance. Similarly, HIV positive people experienced denial, they bargained with the virus and with God, they experienced depression and many achieved a state of relative acceptance.

\section{Category 4: Fear of disclosure}

Almost all of the 22 participants discussed disclosure. Common reasons for non-disclosure were rejection, fear of hurting loved ones, guilt and fear of losing clients or a job. As depicted in Figure 2, respondents typically traveled a path starting with initial non-disclosure, moving gradually through increasing levels of disclosure to total disclosure. The phases in Figure 2 include non-disclosure (except to medical staff who knew the diagnosis), partial disclosure to one group, for example friends, partial disclosure to two groups, for example friends and spouse, partial disclosure to three or more groups, for example friends, spouse, children and extended family, and finally full disclosure, for example to friends, spouse, children, extended family, employer, community and the general public.

Some participants achieved successful disclosure whilst others remained in various states of non-disclosure.

The decision whether or not to disclose presented a dilemma for most participants and was feared. Some feared rejection and others experienced it.

"I was scared to tell my parents or boyfriend or family. Because often when people tell their families, the families reject them. I was scared that they would reject me or discriminate against me".

"This must be my secret for now. After maybe four years or so, I can reveal my status".

"I am the only one who knows I am HIV positive. But with my family I am scared to go there ... I am really scared. With this secret I am the only one ... and the doctor".

"As soon as I told him I was HIV positive, he didn't want to stay with me any longer. He said "I don't love you anymore because you are HIV positive".

"Then in 2002 I told my stepfather and he went crazy and screamed and argued with me and threw me out of the house".

"But even up to today I haven't yet disclosed to my wife ... if she can knows that I am HIV positive, my kids will start running away from me and not eat what I have cooked".

"I want to work and I told them. That is how stupid I was".

"After I was diagnosed, I disclosed on TV and nearly every newspaper knew about my status ... and then my patrons stopped coming to my Tavern".
The decision to disclose was influenced by who was being told, how they were told and the events in the life of both parties. It also depended upon the relationship prior to the individual becoming HIV positive. Some participants mentioned that counselors at the clinic had expressed prejudice. In this situation, the HIV positive person had no control over this disclosure since this particular clinic counselor had access to all HIV test results. Furthermore the prejudice in this case came from the least likely source.

Fear appeared to be a response to the stigma and discrimination associated with a sexually transmitted disease. Individuals were afraid to disclose because of the fear that people would brand them as "bad or having sinned". No matter how an individual acquired HIV, the potential was there for them to be stigmatised.

For some the stigma of HIV was reinforced by parents:

"My mother was against it saying what are people going to say when they find out that you are HIV positive".

"It took me a long time to tell my family. I told my mother in February. She didn't believe me ... she said that's not true. I said if you want the results, I will bring the results".

One participant felt that HIV positive people reinforce public discrimination:

"Where I was living the people used to gossip. But the problem is we HIV people discriminate against ourselves first. We say to ourselves ... what are people going to say ... and we keep quiet. We discriminate by feeling ashamed about ourselves".

Some participants did not disclose for fear of hurting loved ones:

"I haven't told any of my family any of this ... I haven't ... Oh my God ... my mum will die".

"If she can know that I am HIV", she will tell my kids and my kids will suffer".

"I am afraid to tell my children about my HIV ... no, no ... no ... oh I think it would kill them".

Some did not want to disclose at work and others were afraid future employers would find out:

"I don't have to tell them (the company) my status because they will discriminate against me".

"But they said I must not share it with anyone else at work because it will not be good for my work. People talk about HIV and AIDS in a negative way in front of me ... that makes me feel bad".

"Because one thing is for sure ... they always wanted to take me to a doctor for check ups. So obviously if the doctor was going to check me he would find that I am HIV positive". 
For some, disclosing felt positive and reinforcing:

"She asked me why I was wearing an HIV positive T-shirt to which I responded that I too am HIV positive. I counseled her, educated her, gave her information and told her to come to our organization called Friends for Life" where she also applied for a disability grant".

"Even at my church they know I am HIV positive. I encourage people to disclose and to live positive. And I am happy".

"People started gossiping about me. They say look at X, she is HIV positive. But I don't care what they say. It affects me financially but that's all".

"Then I started disclosing and going to the libraries...chatting to other people".

Categories three and four are related in that those who accepted their HIV status were more likely to disclose whereas those in denial were less likely to disclose. Where participants had accepted their HIV positive status and freely disclosed, they were psychologically ready to resume work or seek new work opportunities.

\section{Category 5: Job-related barriers \\ Loss of Job}

Participants reported that becoming infected with HIV led to barriers at work. Some had left their work after acquiring HIV. Six had left due to various forms of discrimination and three had left due to ill health. Reasons included being sick at work, being physically less capable than before, feeling weak and needing to rest, being emotionally distressed and fearing that the employer would find out.

Once participants who were working in formal organisations lost their jobs, they tended not to improve their work level when resuming work at the same or another organisation. This study found that in all cases where jobs were lost, reentry into the marketplace was extremely difficult and the job obtained was at a lower level and very often in the informal sector. For these participants losing their jobs meant unemployment for long periods of time and sometimes indefinitely.

"When I tested I was already not working because I was starting to be with problems at work where I was late and I couldn't keep up anymore ... I was even losing concentration at work".

"I started getting sick. And I hated it that every month I had to be a week away sick. So I decided to resign".

"All of a sudden the supervisor called me aside and said to me that I should go. I knew that they were getting rid of me because of my HIV status, not because of my work".

"I lost my job as electrician at the merchandising company. So ever since then I went back to working at the bottle store of my sister. Then my sister lost the bottle store and I worked for Game for one month as a temporary worker. Ever since then I am not working."

"I was working in the office as an assistant manager. After I left my work, I got a job at a garage as a petrol attendant but ended up going some banking."

Loss of business

In three instances where participants had entrepreneurial experience and wanted to use this experience to continue or start new businesses, public ridicule and discrimination prevented them from continuing.

"After I disclosed my status the people said we are not going to buy my food anymore".
"I used to be a business women ... I used to own a Salon and do catering. I couldn't do this anymore when I became infected. This was because of discrimination".

"I am running a tavern in Soweto. After I was diagnosed, I disclosed on TV and nearly every newspaper knew about my status. And then my patrons stopped coming to my tavern. Because in a tavern we sell liquor and they no longer wanted to buy my beer. And I asked myself ... how could people be so stupid. I am HIV positive but what can I do to a beer?".

\section{Category 6: Coping with HIV}

Coping took place at the physical, psychological, spiritual and relational levels and was related to successes in categories three and four. For many, coping began with self-acceptance, living positively and having an internal dialogue with the virus:

"You should love yourself first".

"So what I believe is you can live longer if you live your life positively".

"The virus hasn't changed me much ... It just made me a better person".

"I find something that can keep me busy ... then I do it".

"... Another thing which makes me feel ok with my status ... is that I talk to my virus. I say that the virus is in MY body... I am not in the body of the virus ... the virus is in MY body (author's emphasis). So every morning when I pray, I say to the virus ... now you listen to me. And my virus really listens to me. The virus hasn't changed me. It has just made me a better person".

"The virus is in MY body. Or she or he has to listen to ME. So I have told the virus, I have got to work ... to see my child grow up ... And I told the virus that if I die, we die together. So what's the use? I know that this virus wants to live in MY body so he (or she) must listen to me. At least I give my virus good food, a good home, what else does it want (laughs)".

"HIV made me a very strong person. I never thought I could stand up and teach large crowds of people about HIV".

Some coped through acquiring education and information. This included knowing one's HIV status, attending counseling and being counseled, teaching and counseling HIV groups, attending HIV support groups.

"Now I am feeling much better because I am attending this group discussion on Friday. So meeting people and talking to them makes you feel much better".

"I never thought I would survive or recover from what I heard the results. But I started attending support groups ...".

Physical coping strategies included, in some cases, taking antiretroviral medication and in others taking immune boosters in the form of vitamins and other immune protectors, eating a healthy diet, exercising, drinking lots of water, getting lots of rest and taking nevirapine in the case of pregnant mothers. Participants appeared to prefer taking immune boosters and avoided taking medication for as long as possible. This could be due to the side effects mentioned by a few participants.

"I take multivitamins ... African potato pills, selenium pills, garlic ... I don't need anti-retrovirals now".

"My CD count has gone up ... because I exercise every day and I eat very healthy food".

"I eat healthy food. I train a lot. I drink a lot of water. I also rest".

"I am taking immune boosters". 
Relational coping strategies included disclosure to and support from friends, disclosure to and support from spouse and family. In all cases, disclosure could only be supportive where it did not result in stigma, blame and rejection.

\section{"The first day when I found out, I told all my friends".}

A significant coping strategy mentioned by participants was faith. Some felt that since God had punished them, God could provide guidance and consolation. Four of the participants hoped that God would provide a miracle cure in the near future.

"I think it's a matter of praying. You must have that belief".

"And I always pray not to be terminal".

"But I have hope that God will provide a cure one day soon".

"Maybe God will forgive me one day and wipe away this disease in my body".

"I want a miracle to happen -it will happen I know ... this sickness is just a punishment from God, I believe ... for our sins. In Sotho, we say God punishes children because of their parents' sins".

Coping was closely related to level four of Maslow's hierarchy, the esteem needs (Maslow, 1998). In an effort to lift levels of selfesteem, participants had dialogues with themselves, with the virus and with God. In the face of public ridicule and in many cases internalised ridicule (self-blame), participants struggled to maintain and to build their self-esteem. According to Maslow (1998) self-esteem must have been achieved if self-actualisation is to be reached. This was evident in this study.

\section{DISCUSSION}

Financial and relationship difficulties emerged as foundational issues that prevented participants from finding and keeping a job. Although these two categories were not directly work issues, they impacted people's capacity to earn a living. Within the financial category the concerns were inability to access education, living in large extended unemployed families, looking after siblings, being the breadwinner from an early age and having children at an early age. Having one or a combination of these circumstances severely curtailed the chances of establishing work which would secure a sustainable livelihood. Whereas the means to acquire schooling and postschool qualifications are often taken for granted by more affluent South Africans, for this sample lack of access to education was a key concern. Furthermore few had the luxury of being able to choose their desired occupation. It is interesting to note that whereas the central focus for organisations like the Treatment Action Campaign and the media is on the availability of anti-retrovirals, access to medication did not emerge as a key concern for this sample.

Viewed as a story in the lives of participants, they appeared to be faced with compounding difficulties. Already facing the hardships of financial and relationship difficulties, they then acquired HIV. At this point they were confronted with two new tasks: The first task required participants to respond to the implications of having acquired the virus and the second task required them to make decisions about disclosure in a hostile environment. Participants thus had to endure the response stages (Figure 1), and negotiate the stages of disclosure (Figure 2 ). Managing these processes enabled participants' to integrate their HIV status into their identity and move on with their lives.

Participants moved from a population of people presumed not to have HIV to a population of people with HIV. In this transition, they faced the tasks of internalising a new identity and coping with discrimination simultaneously. From a positive perspective, discrimination and the difficulties associated with being HIV positive caused a bonding amongst HIV positive people as they formed a sub-culture. Hunt et al. (2003) found that participants experienced fear of discrimination and dilemmas about disclosure. This study found that participants experienced both fear of and actual discrimination in various forms.

The tasks of responding successfully to diagnosis, disclosing and integrating HIV into their lives superseded concerns with getting back to work. However once these tasks had been successfully completed, participants were able to focus on finding work and in several instances, became passionate about working for the HIV cause. This presents an optimistic paradox. This study demonstrates that HIV, which is typically seen as a crisis, has the potential to provide new work opportunities in the HIV industry. In some cases, the crisis of acquiring HIV released a new energy for people to find a new identity, become affiliated to a new sub-culture and find work helping others with HIV. This confirms Riegel's (1979) notion that new opportunities can flow out of a crisis situation.

The findings of this study confirmed those of Hunt et al. (2003) who found that HIV positive people are likely to leave their jobs for various reasons. Although some participants lost their jobs after acquiring HIV, those who had been involved with an occupation or small business before acquiring HIV had a better chance of continuing with these businesses after acquiring HIV. Those who had never worked and who had no work experience before acquiring HIV were less likely to find work even in the informal sector.

Figure 3 represents a holistic picture of the six categories that were identified. The first two categories appear at the base of the figure. These represent the core categories which set the context for the following four. Coming to terms with HIV and having to disclose ones status are grouped together as the next two categories because these are directly related to HIV and AIDS. The fifth category, job-related barriers appears at the pinnacle because this category is specifically related to work. The last category, coping strategies, spans all five because participants must find way to cope with the challenges of all the other categories.

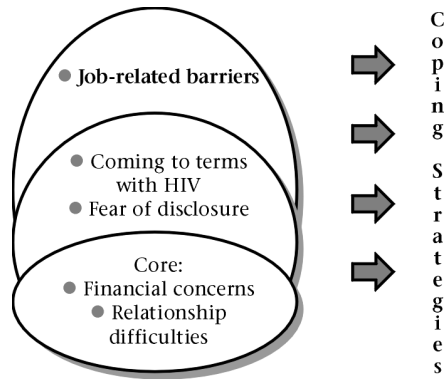

Figure 3: Integrated view of the categories

The categories are related and impact one another. They should thus not be seen as mutually exclusive.

According to Maslow's hierarchy of needs, self-esteem should be achieved before people can self-actualise (Maslow, 1998). Similarly this study reveals that participants had to internalise their diagnosis as part of their identity and disclose this new identity to others, before work issues could be dealt with. Work related concerns therefore need to be understood not only in terms of categories, but also in the context of the process of coming to terms with being HIV positive.

\section{Recommendations}

The work-related concerns identified by participants in this study have numerous implications for the individuals themselves, for organisations and at the level of government. 
When viewed at the level of the individual, the burden and ultimate responsibility for moving forward lies with HIV positive people themselves. Too many participants were sitting back waiting for "a job" to arrive. Some were no longer involved in active job-search or work creation. Taking ownership is more likely to occur when participants have processed the idea of having HIV (moved through the response phases) and built a support system. They would need to achieve psychological readiness and then take action. For the individual to take action, this research suggests that relationship difficulties can be alleviated through attending support groups, obtaining psychological counseling and using peer support groups. This support should not be limited to medical and emotional issues only, but should extend to include work-related issues. Taking action should also include becoming more informed about opportunities. Such opportunities exist within the structures set up by the Skills Development Act, 1998, for example the national skills fund and the Sector Education Training Authority learnership system. HIV positive people should also be creating opportunities for themselves. This could take the form of generating work in the informal sector and through the use of networks in the HIV community.

At the level of business, providing medical aid facilities for antiretroviral drugs and sick leave for illnesses is important. However, organisations need to focus on work-related concerns, for example retaining jobs, equal and fair treatment (a requirement in terms of the Employment Equity Act), and the encouragement of disclosure that is guaranteed to be safe. Maintaining work and income is especially important for an HIV positive person because of the importance of work in boosting self confidence and a sense of self worth. Self-confidence and self worth are the very elements which are eroded both by the HIV positive person him or herself and significant others around them. This presents an opportunity for human resources practitioners to create greater dialogue with HIV positive people and to adopt work-related issues into social responsibility and employee assistance programmes.

Maintaining work and therefore income is important in the face of high levels of unemployment and poverty. It was noted that HIV positive people are likely to lose their jobs or encounter job changes post diagnosis. Human resource managers should be aware of potential job-related disruptions for HIV positive people and be sure that the company or its representatives do not cause these disruptions. A full understanding of the law surrounding HIV and AIDS in the workplace is essential. In addition, a full understanding of the Skills Development Act and the South African Qualifications Authority is important. This, in order to understand opportunities provided to unemployed people through the Sector Education Training Authorities (SETA's), particularly in terms of learnerships being offered to unemployed people. Such learnerships are sponsored by the Sector Education Training Authorities and the government. Specifically, the government offers organisations R25 000 upon signing up a learner and R25 000 when the learner completes the learnership successfully. This offers opportunities for skills development and empowerment, which could be particularly important for HIV positive people. In addition, various youth funds are being sponsored by the government, some through the National Skills Fund (NSF). For example the Youth Internship Programme is sponsored by the Department of Trade and Industry. This programme focuses on promoting the development of Information Technology skills amongst unemployed youth. Youth themselves can apply for these learnerships. In addition, application can be made to this fund by organizations. Currently these funds are not being used effectively and this presents an opportunity.

Some companies have HIV awareness programmes focusing on prevention and voluntary counseling and testing. This is important as it addresses the physical side of HIV and AIDS. This study demonstrates however that stigma, prejudice and discrimination typically have a greater negative effect on the psychological and emotional condition of the infected person. If clinic staff, counselors or managers at work hold or express prejudices even in subtle ways this has the potential of reinforcing general prejudice and damaging self confidence. People with HIV should be seen as no different from any other person. These concerns need to be addressed. Companies may for example consider a sensitization process for anyone tasked with managing the HIV issue in the organization. It may also help, for example for practitioners working with employees to assume that any person could be HIV positive. Making this assumption would give managers new perspective when dealing with staff and sensitive staff related issues. Managers should also be aware of the response phases to HIV and at what physical and emotional stage an individual may be at any point in time.

Apart from having a company policy on HIV and AIDS companies should promote a sense of ownership by stakeholders. People need to confront HIV and become personally involved in combating HIV and AIDS. It should never be a case of "its not my job".

At the national level, government and popular HIV/AIDS action groups have focused on providing medication as a priority in addressing the problem. Although medication is important, for the sample in this study access to jobs and sustainable income in a society and workplace free from stigma and discrimination emerged a more important concern inhibiting people's progress specifically with regard to their working lives.

This offers government departments dealing with HIV and AIDS an opportunity to assist people to get back to work and to establish methods in which people can create a livelihood in the informal sector.

\section{Limitations}

This research was an exploratory study designed to create awareness and give a voice to a relatively voiceless sample of the South African population. The sample comprised largely of single black female heads of households. Results and interpretation are restricted to this sample. Due to the small sample size, caution should be exercised in generalising to the larger population. However, these themes do appear to reflect the current reality of the South African situation.

Initially the sample was sought in the formal corporate sector. Due to the fact that very few people in middle to senior positions disclose their HIV positive status (C. Evian, personal communication, 5 November 2003), the researcher was forced to abandon the formal and search for the sample within the informal sector of the economy.

\section{Conclusion}

Work-related concerns for Black South Africans living with HIV were found to be embedded in the socio-economic fabric of South African society. For many South Africans, dealing with HIV status and AIDS becomes synonymous with dealing with poverty and unemployment. In this context, financial constraints and relationship problems define the way in which work-related issues will be experienced. Although ambition was expressed, the luxury of occupational choice was absent. Human Resource managers and career practitioners should be aware of the basic challenges faced by HIV positive South Africans, for example having limited access to financial and educational resources. It would help if practitioners informed themselves about the mechanisms to access resources for example those being made available by the National Skills Fund and the Sector Education and Training Authorities.

This study offers opportunities for further research. For example there appears to be a relationship between response phases to HIV (Figure 1) and the phases of disclosure (Figure 2). This proposed relationship is depicted in Figure 4. It appears that as people come to terms with their HIV positive diagnosis (and 
Phases in coming to terms with HIV

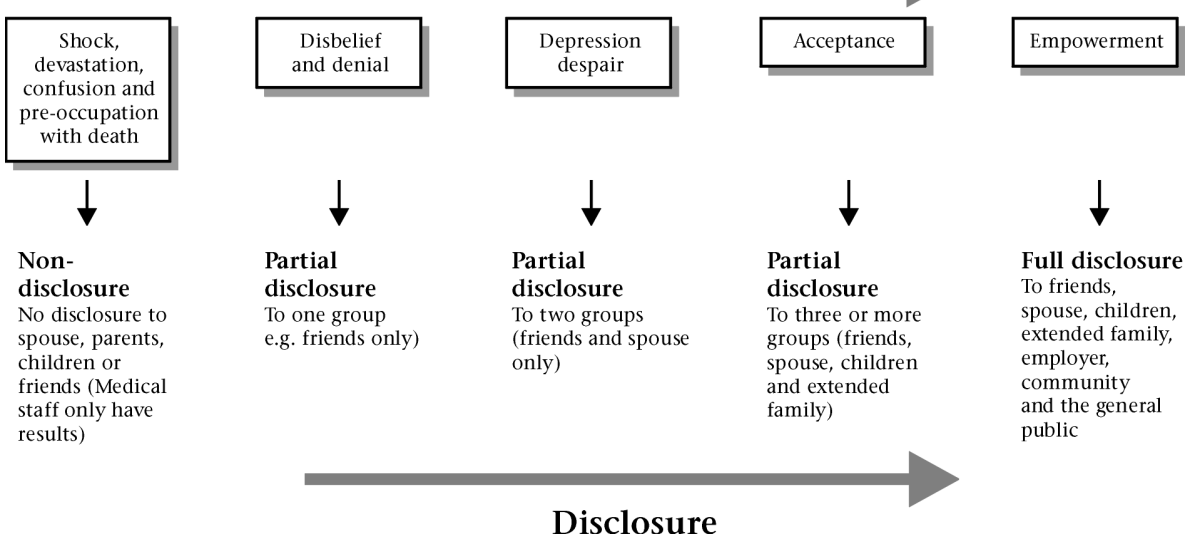

Figure 4: Relationship between response-phases of HIV and disclosure

move along the response phases in Figure 1), so disclosure becomes more likely. When people are still in shock, they are likely to be in a temporary state of non-disclosure as they grapple with the diagnosis. With phases such as disbelief, denial, depression and despair, they are likely to disclose, but to a selected few. Having gained psychological strength from reaching the phases of acceptance and empowerment, disclosure to more people and in some cases public disclosure, becomes more likely. This relationship offers a research opportunity.

In addition, further research on ways in which HIV positive people cope with their diagnosis and forge ahead with their lives would be valuable.

\section{REFERENCES}

Babbie, E. \& Mouton, J. (2001). The practice of social research. Cape Town: Oxford University Press.

Bartos, M. \& McDonald, K. (2000). HIV as identity, experience or career. AIDS care, 12 (3), 299-307.

De Vault, M.L. (1999). Liberating method: fiminism \& social research. Philadelphia: Temple University Press.

Esterberg, K.G. (2002). Qualitative methods in social research. Lowell: McGraw-Hill.

Gergen, M. \& Gergen, K. (2003). Social construction: A Reader. London: SAGE.

Hoffman, M.A. (1997). Counseling the HIV-infected client: A psychosocial model for assessment and intervention. The Counseling Psychologist, 19, 467-542.

Hunt, B., Jacques, J., Niles, S.G. \& Wierzalis, E. (2003). Career concerns for people living with HIV/AIDS. Journal of Counseling and Development, 81, 55-61.
Jackson, H. (2002). AIDS Africa: Continent in crisis. SAfAIDS, Zimbabwe.

Kingdon, G.G. \& Knight, J. (2001). Unemployment in South Africa: The nature of the beast. Centre for the Study of African Ecomonies, University of Oxford.

Klasen, S. (2000). Measuring poverty and deprivation in South Africa. Review of Income and Wealth, 46, 1-25.

Kubler-Ross, E. (1970). On death and dying. New York: Macmillan.

Lukas, E. (1997). The meaning of life and goals in life for the chronically ill. In F. Crous, A.A. Havenga Coetzer, \& G. van den Heever (Eds.), On the way to meaning: Essays in remembrance of Viktor Frankl (pp.115-125). Johannesburg: Viktor Frankl Foundation of South Africa.

Maslow, A.H. (1998). Maslow on management. New York: Wiley

Riegel, K.F. (1979). Foundations of dialectical psychology. New York: Academic press.

Schreuder, A.M.G. \& Theron, A.L. (2001). Careers: An organisational perspective. (2nd ed.). Johannesburg: Juta.

Shantall, T. (1997). What is meant by meaning?. In F. Crous, A.A. Havenga Coetzer, \& G. van den Heever (Eds.), On the way to meaning: Essays in remembrance of Viktor Frankl (pp.57-72). Johannesburg: Viktor Frankl Foundation of South Africa.

Silverman, D. (2000). Doing qualitative research: A practical handbook. London: SAGE.

Smaling, A. (1992). Objectivity, reliability and validity. In G.J.N. Bruinsma \& M.A. Zwanenburg (Eds). Methodology for management specialists. Muiderberg: Coutinho.

UNAIDS. (2002). Report on the Global HIV/AIDS Epidemic, July 2002.

Van Dyk, A. (2001). HIV/AIDS care and counseling: A multidisciplinary approach. (2nd ed.). Cape Town: Pearson. 